\title{
The effect of air-bubble washing with natural sanitizers on microbial contamination and quality characteristics of perilla seeds
}

\author{
Ah-Na Kim ${ }^{1}$, Kyo-Yeon Lee ${ }^{1}$, Myeong-Hwa $\mathrm{Ha}^{2}$, Myoung Hee $\mathrm{Lee}^{3}$, Jung In Kim ${ }^{3}$, \\ Doyeon $\mathrm{Kwak}^{3}$, Sung-Gil Choi ${ }^{1,4 *}$ \\ ${ }^{1}$ Division of Applied Life Science, Gyeongsang National University, Jinju 52828, Korea \\ ${ }^{2}$ Division of the Support and Planning, Gyeongsangnam-do Agricultural Research and Extension Services, Jinju 52733, Korea \\ ${ }^{3}$ Department of Southern Area Crop Science, NICS, RDA, Miryang 50424, Korea \\ ${ }^{4}$ Division of Food Science and Technology (Institute of Agriculture and Life Scieces), Gyeongsang National University, \\ Jinju 52828, Korea
}

\section{버블 침지 세척과 천연 세척보조제가 들깨의 미생물 저감화 및 품질특성에 미치는 영향}

\author{
김아나 ${ }^{1} \cdot$ 이교연 ${ }^{1} \cdot$ 하명화 $^{2} \cdot$ 이명희 $^{3} \cdot$ 김정인 $^{3} \cdot$ 곽도연 $^{3} \cdot$ 김현진 $^{1,4} \cdot$ 최성길 ${ }^{1,4 *}$ \\ ${ }^{1}$ 경상대학교 응용생명과학부 응용생명과학전공, ${ }^{2}$ 경상남도농업기술원 지원기획과, ${ }^{3}$ 국립식량과학원 남부작물부 \\ ${ }^{4}$ 경상대학교 농화학식품공학과( 농업생명과학연구원)
}

\begin{abstract}
The purpose of this study was to evaluate the effect of air-bubble washing with natural sanitizers on microbial contamination such as aerobic bacteria, yeast, and mold, and the quality characteristics of perilla seeds. Bubble washing was more effective than immersion washing for all washing times. The microorganism counts decreased as a function of bubble washing time, with an optimum air-bubble washing time of $60 \mathrm{~min}$. In addition, immersion and bubble washing with natural sanitizers such as vinegar and brine of $1,2.5$, and $5 \%$ caused a dramatic decrease in the microorganism counts compared with washing without sanitizers. There was no significant difference between $\mathbf{2 . 5 \%}$ and $\mathbf{5 \%}$ vinegar in bubble washing efficacy. The results of bubble washing with brine were similar to those of bubble washing with vinegar, but vinegar resulted in more effective microbial decontamination than brine at all concetrations. In addition, bubble washing with vinegar and brine did not alter the oxidative stability of perilla seeds as determined by acid and peroxide values. As a result, air-bubble washing with natural sanitizers is an effective method to reduce the microbial contamination and enhance the microbiological safety of perilla seeds.
\end{abstract}

Key words : air bubble washing, microbial decontamination, perilla seeds, natural sanitizers

\section{서 론}

들깨(Perilla frutescens var. japonica Hara)는 꿀풀과 (Laviatae)의 1년생 초본으로 원산지는 동부 아시아 지역으

*Corresponding author. E-mail : sgchoi@gnu.ac.kr

Phone : ※ 개인정보 표시제한, Fax : 82-55-772-1909

Received 20 August 2018; Revised 5 October 2018; Accepted 8 October 2018

Copyright (c) The Korean Society of Food Preservation. All rights reserved.
로서 인도, 한국 및 중국 동북부 지역에서 예로부터 재배되 어온 대표적인 유지작물중의 하나이다 $(1,2)$. 들깨는 다른 작물에 비해 병해에 강하고 재배지역 및 토양에 대한 적응 성이 높으며, 파종기의 이동범위가 넓어 타작물과의 윤작 이나 혼작이 가능하여 작부체계상 중요한 작물로 평가되고 있다(3). 또한 들깨는 외국에서 거의 생산되지 않아 농산물 개방에 따른 압력이 없는 작물로, 수입개방화 된 지금 경쟁 력 대체작물로 분류된 유일한 유지작물로 평가되고 있으 며, 우리나라의 고소득 작물 중 하나로 손꼽히고 있다 $(4,5)$ 이에 따라 들깨의 생리활성을 규명하고자 하는 연구가 진행 
되고 있으며, 높은 항산화 활성(6)과 항암(7) 및 항염증(8), 혈압 감소 및 동맥경화 예방 등의 지질대사 개선(9) 효과 등 우수한 기능적 특성이 보고되고 있다. 하지만 현재까지 들깨의 주요 생리활성 물질 분석과 생리활성 평가에 관한 국내 연구로 국한되어 있으며, 고부가가치 작물로의 산업 화 및 세계화를 위한 수확 후 품질관리에 관한 연구는 부족 한 실정이다(9).

수확 후 관리는 산물을 선별, 저장 전 처리, 저장, 포장, 수송 등의 일련의 과정을 통해 수확부터 소비자에 이르기까 지 신선하고 안전하게 전달하는 데 있어 필요한 모든 관리 기술이다(10). 최근 안전 농산물에 대한 요구가 증가하면서 농산물의 체계적인 수확 후 관리를 통해 지속적인 안전 농산물의 생산 및 유통이 중요시 되고 있다(11). 이를 위해 서 수확 후 관리의 단계 중 하나인 세척 기술을 통해 식품에 존재하는 미생물 번식과 관련한 안전성 확보가 필요하다. 들깨의 경우 토양 미생물과 수확, 선별 및 수송과정 중 각종 오염원에 의한 표면 오염이 위생상 문제가 되고 있지만, 일반 농가에서는 수도수 침지 방법만으로 세척을 실시하고 있다. 이에 따라 체계적인 세척 기술을 통해 오염 미생물을 제어할 필요가 있지만 들깨의 위생적 세척방법에 대한 연구 는 전무한 실정이다.

최근에 식품의 위생적 안전성을 확립하기 위해 이온화 조사, 초음파, 자외선, 버블기술 등의 세척 기술이 연구되고 있다(12). 그 중 버블을 이용한 세척 기술은 식품 자체가 가지는 이화학적 품질 특성에 미치는 영향이 가장 적은 친환경적인 위생적 세척기술로 알려져 있다. 이는 센티미 터 단위의 기포가 수면 위로 빠르게 상승하여 파열하는 세척 방식이며, 버블에 의해 오염물의 폭기와 부유 등을 발현함으로써 원료 표면으로부터 이물질 및 미생물이 효과 적으로 분리되는 세척방법이다(13). 이는 일반적으로 사용 하는 침지 세척방식과는 달리 살균 용액과 접촉이 어려운 취약 부분에 대한 살균 효과를 기대할 수 있는 장점이 있다 (13-15). 이러한 세척 방법은 환경정화, 의료분야, 수산분야, 반도체 분야, 정수용 등에 적용되고 있지만, 초기단계의 연구에 머무르고 있어 더욱더 체계적인 연구가 필요한 실정 이다(15). 또한, 식품 미생물 수의 저감효과를 향상시키기 위해 사용되는 살균소독제인 염소 용액은 항균작용이 뛰어 나지만 trihalomethanes(THM), 염화페놀 등의 독성물질이 생성되어 환경과 건강에 악영향을 미치는 것으로 알려져 있다(16). 이에 따라 화학약제를 대체할 수 있는 천연물질을 이용하여 미생물학적 안전성을 확보하려는 연구가 필요한 실정이다.

따라서 본 연구에서는 버블세척 시간에 따른 들깨의 미 생물 저감 효과를 통해 적정 세척시간을 측정하였고, 천연 세척보조제인 식초와 염수를 이용한 버블세척을 통해 살균 효과와 품질특성에 미치는 영향을 비교 분석함으로써 들깨 의 위생적 천연 세척기술을 구축하고자 하였다.

\section{재료 및 방법}

\section{실험 재료}

본 실험에서 사용한 들깨는 '다유' 품종으로 충북농업기 술원에서 2017년 6월에 수확한 것을 제공받아 $5^{\circ} \mathrm{C}$ 에서 보 관하며 사용하였다.

\section{세척 처리}

들깨의 세척은 버블세척기(Kyeongchang Food Equipment, Jinju, Korea)를 이용하여 침지(batch) 방식으로 실시하였다. 먼저, 버블세척기의 A chamber에 약 $5 \mathrm{~L}$ 의 세척수 $\left(20 \pm 1^{\circ} \mathrm{C}\right)$ 를 넣은 다음, 공기방울이 통과할 수 있도록 제작된 체에 약 $50 \mathrm{~g}$ 의 들깨를 놓은 후 이를 세척수에 담궜다. Air blower(A)를 통해 생성되는 공기방울로 버블세척을 실시한 후 시료가 든 체를 B chamber에 옮겨 shower(B)를 이용해 정제수로 10 초 동안 세척수를 제거하고, 공기를 1 분 동안 분사하여 시료 표면의 물기를 제거하였다. 버블세척 시간 에 따른 미생물 저감 효과를 알아보기 위해 $0,10,20,30$, 60,90 분간 버블세척을 실시하였으며, 버블세척과 동일한 조건 하에서 공기방울을 투입하지 않고 세척수에 침지한 것을 대조구로 하였다.

버블세척 시 세척수에 용해된 천연 세척보조제가 들깨의 미생물 저감에 미치는 영향을 알아보기 위해, 초산과 염의 농도에 따른 세척효과를 분석하였다. 식초의 경우 식용 빙 초산(Chunwoo Food, Cheongdo, Korea)을 이용하였고, 염수 는 시판 정제염(Hanju salt, Ulsan, Korea)을 이용하였다. 빙 초산과 염 모두 $1,2.5,5 \%$ 의 농도로 세척수에 용해하였고, 세척시간은 버블세척 시간에 따른 미생물 저감효과를 분석 한 결과를 통해 선정된 최적 버블세척 시간 동안 실시하였 다. 또한, 버블세척 효과를 알아보기 위해 버블세척과 동일 한 조건 하에서 공기방울을 투입하지 않고 같은 농도의 천연 세척보조제가 첨가된 세척수에 침지한 것을 대조구로 하여 비교하였다. 세척 시 흡습된 수분을 제거하기 위해 들깨의 수분함량이 $2 \%$ 에 도달할 때까지 $20^{\circ} \mathrm{C}$ 에서 냉풍 건 조를 실시하였으며, 건조한 들깨의 미생물 수와 품질특성 을 분석하였다.

\section{미생물 수 측정}

버블세척 및 천연 세척보조제에 따른 들깨의 미생물 저 감효과를 알아보기 위해서 일반세균, 대장균군, 효모 및 곰팡이 수를 측정하였다. 세척 후 냉풍 건조한 약 $5 \mathrm{~g}$ 의 시료를 멸균된 stomacher bag에 넣은 후 $0.85 \%$ 멸균생리식 염수로 10 배 희석하여 stomacher로 2 분간 균질화하였다. 이후 10 배씩 단계별 희석하여 시료를 준비하였으며 희석한 시료 $1 \mathrm{~mL}$ 를 일반세균 Petrifilm ${ }^{\mathrm{TM}}$ aerobic count plate( $3 \mathrm{M}$ Company, St. Paul, MN, USA)에 접종하였다. 배지를 $35^{\circ} \mathrm{C}$ 에 서 48시간 배양하여 $30-300$ 개 사이의 colony 수를 측정하였 
다. 대장균군은 위의 방법과 동일하게 단계 희석하여 Petrifilm ${ }^{\mathrm{TM}}$ coliform count plate(3M Company)에 접종하였 고 $35^{\circ} \mathrm{C}$ 에서 24 시간 배양 후 기포를 가진 red colony만을 확인하였다. 효모 및 곰팡이는 위의 방법과 동일하게 단계 희석하여 Petrifilm ${ }^{\mathrm{TM}}$ yeast \& mold count plate( $3 \mathrm{M}$ Company)에 접종하였고 $25^{\circ} \mathrm{C}$ 에서 5 일간 배양 후 green, yellow, pink 등의 모든 colony를 측정하였다. 일반세균, 대 장균군, 효모 및 곰팡이는 시료 $1 \mathrm{~g} \mathrm{DW}$ (dry weight) 당 colony-forming units(CFU)을 $\log$ 단위로 환산하여 표시하 였다.

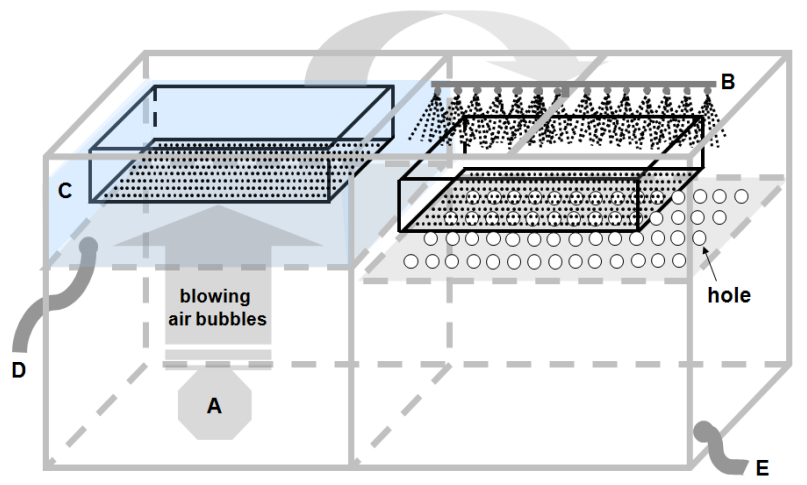

Fig. 1. Scheme of air bubble washing equipment.

A, air blower; B, shower (water \& air bubbles); C, soaking foods in vinegar or brine; $\mathrm{D}$ and $\mathrm{E}$, drain.

버블세척 및 천연 세척보조제에 따른 산화 안정성 분석

버블세척 및 천연 세척보조제가 들깨의 산화 안정성에 미치는 영향을 알아보기 위해 들깨의 대표적인 산화 안정성 평가 지표인 산가와 과산화물가를 측정하였으며, 최적 버 블세척시간 동안 처리한 시료와 천연 세척보조제가 첨가된 세척수를 이용하여 버블세척한 시료의 산가와 과산화물가 를 비교하였다. 이때 세척하지 않은 시료를 대조구로 하였 다. 산가의 측정은 식품공전(17)의 방법에 따라 실시하였다. 추출한 유지 약 $1 \mathrm{~g}$ 을 삼각플라스크에 취한 후, ethyl ether:ethanol(2:1, v/v) $20 \mathrm{~mL}$ 를 넣고 진탕하여 완전히 용해 시킨 후 $1 \%$ 페놀프탈레인 용액을 지시약으로 하고, 0.1 $\mathrm{N} \mathrm{KOH}$ 에탄올 용액으로 적정하여 미홍색이 30 초간 유지 되는 때를 종말점으로 하여 3회 반복 측정하였다. 과산화물 가의 측정은 식품공전(17)의 방법에 따라 측정하였다. 즉 추출한 유지 약 $1 \mathrm{~g}$ 을 삼각플라스크에 취한 후, acetic acid:chloroform(3:2, v/v) $25 \mathrm{~mL}$ 를 가하여 혼합하고 KI 포화 용액 $1 \mathrm{~mL}$ 를 가하여 교반한 후 암실에 10 분간 방치하였다. 반응 후 증류수 $30 \mathrm{~mL}$ 를 가하여 진탕하고 $1 \%$ 전분용액을 지시약으로 하여 $0.01 \mathrm{~N} \mathrm{Na}_{2} \mathrm{~S}_{2} \mathrm{O}_{3}$ 용액으로 청색이 소실되 는 시점을 종말점으로 하여 3 회 반복 측정하였다.

\section{통계분석}

실험 결과는 6 회 및 3 회 반복 실험하여 얻어진 평균 \pm 표준
편차로 나타내었고, 통계처리는 Window용 SAS 9.4 version(SAS Institute Inc., Cary, NC, USA)을 이용하여 $\mathrm{p}<0.05$ 수준에서 분산분석(analysis of variance) 하였으며, Duncan의 다중범위 검정법(Duncan's multiple range test)으 로 유의성을 검증하였다.

\section{결과 및 고찰}

\section{세척시간에 따른 미생물 수}

버블세척에 따른 들깨의 미생물 제거 효과를 확인하기 위해 일반 침지 세척을 대조군으로 하여 세척시간에 따라 일반세균, 효모 및 곰팡이수를 측정하였으며, 그 결과는 Fig. 2와 같다. 모든 시료에서 대장균군이 검출되지 않았으 며, 세척 전 들깨의 일반세균과 효모 및 곰팡이 수는 각각 $7.31,5.08,5.12 \log \mathrm{CFU} / \mathrm{g}$ 으로 나타났다. Solberg 등(18)은 섭취 직전의 식품의 총균수가 $5 \log \mathrm{CFU} / \mathrm{g}$ 이하일 경우 위생적 안전성을 확보할 수 있다고 보고하였다. 식품의약 품안전처에서 발표한 식품공전에서는 신선편의식품을 포 함한 즉석식품의 세균수 허용기준을 $1 \mathrm{~g}$ 당 100,000 이하로 보고하였다(17). 최근 농산물의 경우 미생물 안전성 확보에 대한 문제점이 지적되고 있으며, 수출 시 규제가 될 수 있기 때문에 미생물의 오염수준을 제어하는 수단에 대한 연구가 필요하다고 보고하였다(19-21).

일반 침지와 버블세척한 처리군 모두 세척시간이 길어질 수록 일반세균과 효모 및 곰팡이 수가 감소하는 것으로 나타났다. 20분 이상 세척 시 일반 침지한 시료보다 버블세 척한 시료의 일반세균 수가 유의적으로 적은 것으로 나타났 다. 또한 일반 침지와 버블세척을 60 분간 실시하였을 때 들깨의 일반세균 수는 각각 $37.04 \%$ 와 $50.58 \%$ 감소하는 것 으로 나타났고, 두 세척 방법 모두 60 분과 90 분 세척 시 유의적 차이가 없는 것으로 나타났다. 효모 및 곰팡이의 경우에는 모든 세척시간에서 버블세척한 들깨가 일반 침지 한 들깨보다 유의적으로 세척 효과가 우수한 것으로 나타났 다. 일반세균 결과와 같이 버블세척한 들깨의 효모 및 곰팡 이 수는 각각 $52.86 \%$ 와 $61.76 \%$ 의 저감률을 나타내었고, 60 분 이상 버블세척 시 유의적인 차이가 나타나지 않았다. 따라서 들깨의 위생적 세척을 위한 최적 버블세척 시간은 60 분으로 나타났다. Kang 등(14)은 오디를 30 분간 버블세 척 시 일반세균과 효모 및 곰팡이 수가 각각 약 $40 \%$ 와 $30 \%$ 저감되었다고 보고하였다. Lee 등(12)은 마이크로버 블 세척시간이 길어질수록 상추의 총 균수를 감소시키는데 효과적이었으며, 손세척구와 비교하였을 때 세척효과가 우 수했다고 보고하였다. Lee 등(12)과 Kang 등(14)은 버블이 식품 표면의 이물질 및 미생물을 분리시킴으로써 위생적 세척을 실시할 수 있다고 보고하였다. 


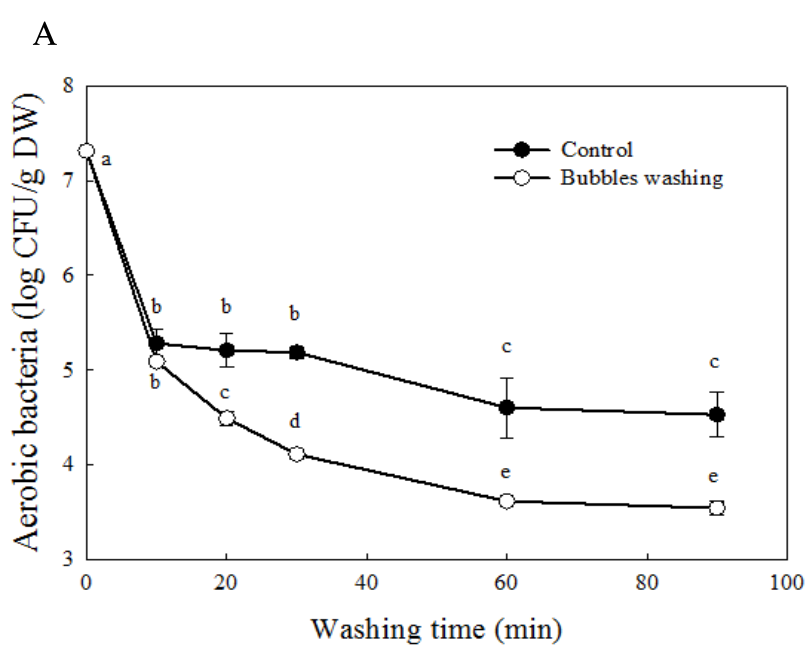

B

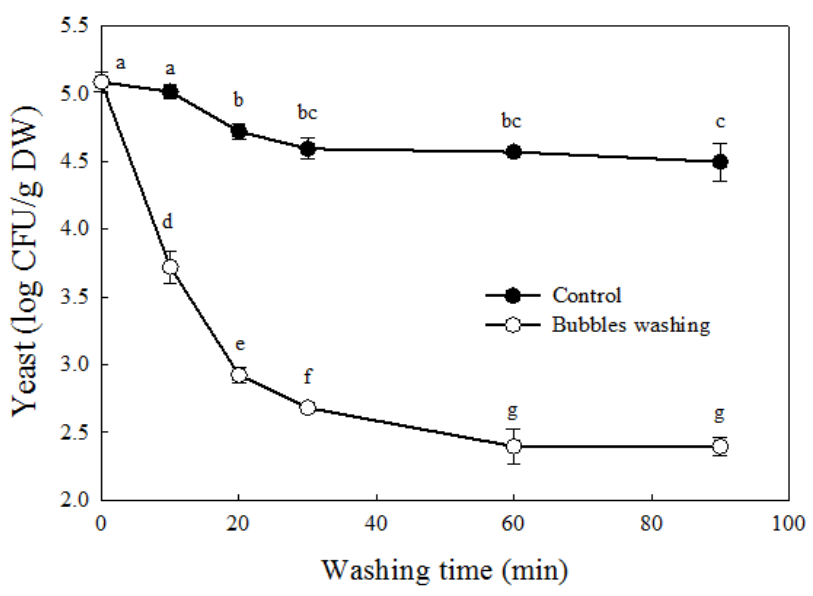

C

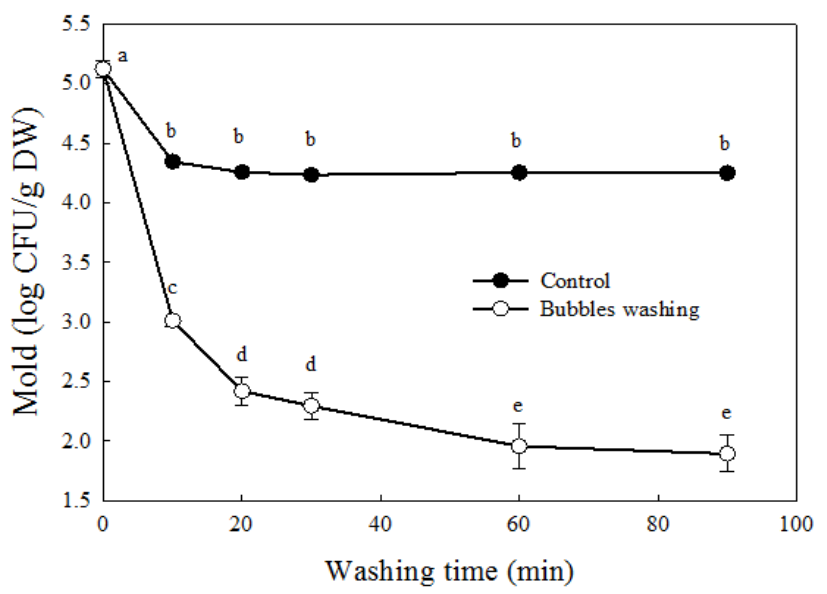

Fig. 2. Changes in the number of (A) aerobic bacteria, (B) yeast, and (C) mold as a function of washing time of perilla seeds.

Control, immersion washing without blowing air-bubbles.

\section{천연 세척보조제를 이용한 세척에 따른 미생물 수}

세척 시 천연 세척보조제로서 식초와 염수의 적용에 따 른 미생물 저감 효과를 확인하기 위해 $1,2.5,5 \%$ 의 농도로
제조한 식초와 염수를 세척수로 하여 최적 세척시간으로 선정된 60 분 동안 일반 침지와 버블세척을 실시하였고, 이 에 따른 일반세균과 효모 및 곰팡이 수를 분석하였다. 먼저, 천연 세척보조제로 식초를 농도별로 사용하여 세척한 결과 는 Table 1 과 같다. 일반 침지와 버블세척 모두 세척보조제 없이 처리한 시료보다 식초를 세척보조제로 사용하였을 때 미생물 수가 효과적으로 감소하는 것으로 나타났다. 또 한 세척보조제로 식초를 적용했을 때 일반 침지보다 버블세 척 시 미생물 저감효과가 우수한 것으로 나타났다. 세척수 에 용해된 초산의 농도가 높아질수록 일반 침지와 버블세척 한 들깨 모두 일반세균 수가 감소하였고, 초산 $2.5 \%$ 와 $5 \%$ 로 버블세척한 시료의 일반세균 수의 감소율은 각각 $62.80 \%$ 와 $62.94 \%$ 으로 유의적인 차이가 나타나지 않았다. 효모의 경 우, 초산 $1 \%$ 농도 이상의 세척수로 처리하였을 때 일반 침지와 버블세척한 들깨에서 모두 검출되지 않았다. 또한 일반 침지와 버블세척 시 각각 초산 $2.5 \%$ 와 $1 \%$ 농도 이상의 세척수에서 처리하였을 때 곰팡이가 검출되지 않는 것으로 나타났다. 초산과 젓산 등과 같은 유기산을 이용하여 세척 을 실시했을 때 세척수의 $\mathrm{pH}$ 가 산성이 되어 미생물의 세포 막이 수소이온으로 포화되고 세포의 투과성이 영향을 주어 미생물이 파괴된다고 알려져 있다(22). 이와 같이 $\mathrm{Kim}$ 등 (23)은 식초용액을 이용하여 채소를 침지 세척하였을 때 총 균수의 미생물 살균효과는 식초농도가 증가할수록 컸다 고 보고하였다. 또한 Kang 등(14)은 식초액을 이용하여 오 디의 버블세척을 실시했을 때 식초의 농도가 높아질수록 일반세균 수가 감소하였다고 보고하였다.

천연 세척보조제로 염을 농도별로 사용하여 들깨를 세척 한 결과는 Table 2 와 같다. 일반 침지와 버블세척 시 세척보 조제를 사용하지 않은 시료보다 염수를 이용하여 세척한 시료의 미생물 저감 효과가 높은 것으로 나타났으며, 일반 침지한 시료보다 버블세척한 시료의 미생물 세척 효과가 우수한 것으로 나타났다. 또한 세척수에 용해된 염의 농도 가 높아질수록 미생물 수가 감소하는 것으로 나타났으며, 염 $2.5 \%$ 로 버블세척 시 $59.11 \%$ 의 일반세균 수가 감소하였 고 염 $5 \%$ 로 버블세척한 시료의 일반세균 수와 유의적 차이 가 없었다. 또한 효모 및 곰팡이의 경우 일반 침지한 시료에 서 염 농도에 따른 유의적인 차이가 없었지만, 버블세척한 시료의 경우 $2.5 \%$ 이상의 염수로 처리하였을 때 검출되지 않는 것으로 나타났다. 본 연구결과와 같이 Kang 등(24)은 버블세척 시 염수를 이용한 세척은 딸기의 미생물 저감 효과를 증가시켜 준다고 보고하였으며, Kang 등(14)은 버 블세척 시 세척 후의 염 농도가 증가할수록 일반세균 수의 감소 효과가 크다고 보고하였다. Lee 등(25)과 Park 등(26) 은 염은 삼투압 현상으로 인한 세포막 손상으로 부패균의 번식을 억제하는데 사용되며, 고염 환경에서 일부 내염성 미생물을 제외한 대부분의 미생물은 급격히 사멸하게 된다 고 보고하였다. 
Table 1. The number of aerobic bacteria, yeast, and mold of perilla seeds treated by control and air bubble washing with vinegar at different levels for $60 \mathrm{~min}$

\begin{tabular}{|c|c|c|c|c|c|}
\hline \multirow{2}{*}{ Microorganisms } & \multirow{2}{*}{ Treatments } & \multicolumn{4}{|c|}{ Vinegar concentration $(\%)$} \\
\hline & & 0 & 1 & 2.5 & 5 \\
\hline \multirow{2}{*}{ Aerobic bacteria } & Control $^{1)}$ & $4.64 \pm 0.34^{2 / 2 \mathrm{a} 3)}$ & $4.30 \pm 0.18^{b}$ & $4.21 \pm 0.15^{c}$ & $3.71 \pm 0.22^{\mathrm{d}}$ \\
\hline & Bubble washing & $3.63 \pm 0.04^{\mathrm{e}}$ & $2.85 \pm 0.19^{\mathrm{f}}$ & $2.72 \pm 0.07^{\mathrm{g}}$ & $2.71 \pm 0.06^{\mathrm{g}}$ \\
\hline \multirow{2}{*}{ Yeast } & Control & $4.57 \pm 0.04^{\mathrm{a}}$ & $\mathrm{ND}^{4) \mathrm{c}}$ & $\mathrm{ND}^{\mathrm{c}}$ & $\mathrm{ND}^{\mathrm{c}}$ \\
\hline & Bubble washing & $2.40 \pm 0.13^{b}$ & $\mathrm{ND}^{\mathrm{c}}$ & $\mathrm{ND}^{\mathrm{c}}$ & $\mathrm{ND}^{\mathrm{c}}$ \\
\hline \multirow{2}{*}{ Mold } & Control & $4.25 \pm 0.01^{\mathrm{a}}$ & $1.80 \pm 0.35^{\mathrm{c}}$ & $\mathrm{ND}^{\mathrm{d}}$ & $\mathrm{ND}^{\mathrm{d}}$ \\
\hline & Bubble washing & $1.96 \pm 0.19^{\mathrm{b}}$ & $N D^{d}$ & $\mathrm{ND}^{\mathrm{d}}$ & $\mathrm{ND}^{\mathrm{d}}$ \\
\hline
\end{tabular}

${ }^{1)}$ Control, immersion washing without blowing air-bubbles.

${ }^{2)}$ All values are mean $\pm \mathrm{SD}(\mathrm{n}=6)$.

${ }^{3}$ Different letters superscript indicate in the same column that means are significantly different $(\mathrm{p}<0.05)$ by Duncan's multiple range test.

${ }^{4} \mathrm{ND}$, not detected.

Table 2. The number of aerobic bacteria, yeast, and mold of perilla seeds treated by control and air bubble washing with salt solution at different levels for $60 \mathrm{~min}$

$(\log \mathrm{CFU} / \mathrm{g} \mathrm{DW})$

\begin{tabular}{cccccc}
\hline \multirow{2}{*}{ Microorganisms } & Treatments & \multicolumn{4}{c}{ Salt concentration (\%) } \\
\cline { 3 - 6 } & & 0 & 1 & 2.5 & 5 \\
\hline \multirow{2}{*}{ Aerobic bacteria } & Control & $4.64 \pm 0.34^{2) \text { a3 })}$ & $4.52 \pm 0.25^{\mathrm{a}}$ & $4.35 \pm 0.09^{\mathrm{b}}$ & $4.29 \pm 0.04^{\mathrm{b}}$ \\
& Bubble washing & $3.63 \pm 0.04^{\mathrm{c}}$ & $3.19 \pm 0.16^{\mathrm{d}}$ & $2.99 \pm 0.28^{\mathrm{e}}$ & $2.87 \pm 0.12^{\mathrm{e}}$ \\
\hline \multirow{2}{*}{ Yeast } & Control & $4.57 \pm 0.04^{\mathrm{a}}$ & $2.76 \pm 0.16^{\mathrm{b}}$ & $2.65 \pm 0.27^{\mathrm{b}}$ & $2.64 \pm 0.27^{\mathrm{b}}$ \\
& Bubble washing & $2.40 \pm 0.13^{\mathrm{c}}$ & $2.05 \pm 0.28^{\mathrm{d}}$ & $\mathrm{ND}^{4) \mathrm{e}}$ & $\mathrm{ND}^{\mathrm{e}}$ \\
\hline \multirow{2}{*}{ Mold } & Control & $4.25 \pm 0.01^{\mathrm{a}}$ & $3.04 \pm 0.36^{\mathrm{b}}$ & $3.01 \pm 0.37^{\mathrm{b}}$ & $2.98 \pm 0.17^{\mathrm{b}}$ \\
& Bubble washing & $1.96 \pm 0.19^{\mathrm{c}}$ & $1.74 \pm 0.21^{\mathrm{d}}$ & $\mathrm{ND}^{\mathrm{e}}$ & $\mathrm{ND}^{\mathrm{e}}$ \\
\hline
\end{tabular}

${ }^{1)}$ Control, immersion washing without blowing air-bubbles.

${ }^{2)}$ All values are mean $\pm \mathrm{SD}(\mathrm{n}=6)$.

${ }^{33}$ Different letters superscript indicate in the same column that means are significantly different $(\mathrm{p}<0.05)$ by Duncan's multiple range test.

${ }^{4} \mathrm{ND}$, not detected.

위의 결과를 바탕으로 식초와 염수를 각각의 농도별로 버블세척한 들깨의 일반세균 수를 비교하였으며, 그 결과 는 Fig. 3과 같다. 염수를 이용한 버블세척은 염의 농도가 높아짐에 따라 일반세균 수의 저감효과가 높아지는 것으로 나타났으며, 식초를 이용한 버블세척은 $2.5 \%$ 와 $5 \%$ 의 농도 에서 유의적인 차이가 없었다. 또한 두 세척보조제의 버블 세척효과를 비교해보았을 때, $2.5 \%$ 이상 농도의 식초를 이용한 버블세척이 가장 유의적으로 우수한 일반세균 저감 효과를 가지는 것으로 나타났다. 효모 및 곰팡이의 경우 세척보조제로 염수와 식초를 이용했을 때 각각 $2.5 \%$ 와 $1 \%$ 이상의 농도에서 버블세척 시 검출되지 않는 것으로 나타났 다. 결과적으로 모든 천연 세척보조제 농도에서 염수보다 식초를 이용하였을 때 들깨의 버블세척효과가 더 우수한 것으로 나타났다.

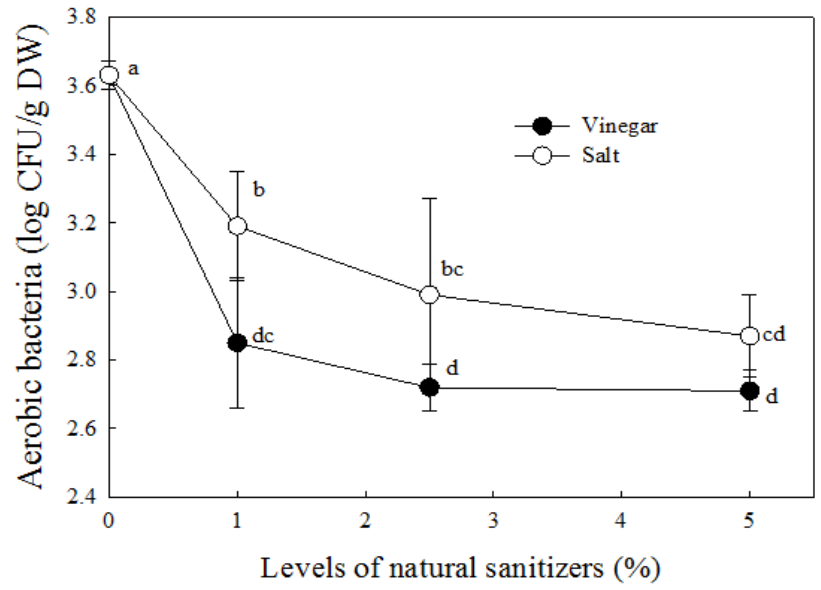

Fig. 3. Changes in the number of aerobic bacteria of perilla seeds treated by air bubble washing with natural sanitizers such as vinegar and salt solution at different levels for $60 \mathrm{~min}$. 
버블세척 및 천연 세척보조제에 따른 산화 안정성 분석

버블세척과 천연 세척보조제가 들깨의 산화 안정성에 미치는 영향을 알아보기 위해서 들깨의 대표적인 품질지표 인 산가와 과산화물가를 분석하였으며, 그 결과는 Table 3 과 같다. 세척 전 들깨의 산가와 과산화물가는 각각 1.13 $\mathrm{mg} \mathrm{KOH} / \mathrm{g}$ 과 $2.01 \mathrm{meq} / \mathrm{kg}$ 으로 나타났으며, 60분 버블세척 시 산가와 과산화물가의 유의적인 차이는 나타나지 않았 다. 또한 초산을 세척보조제로 사용하여 버블세척을 실시 한 들깨의 산가와 과산화물가는 모든 초산 농도에서 세척 전과 유의적인 차이가 없었다. 염수를 이용한 버블세척의 경우 들깨의 산가와 과산화물가에 영향을 미치지 않는 것으 로 나타났다. 결과적으로 천연 세척보조제로 초산 또는 염 을 적용할 경우, 세척 시 들깨의 산화 안정성에 영항을 주지 않으므로 천연 세척보조제로 적합한 것으로 판단된다.

Table 3. Oxidative stability such as acid value and peroxide value of perilla seeds treated by air bubble washing with natural sanitizers solution for $60 \mathrm{~min}$

\begin{tabular}{cccc}
\hline \multirow{2}{*}{$\begin{array}{c}\text { Natural } \\
\text { sanitizers }\end{array}$} & $\begin{array}{c}\text { Concentration } \\
(\%)\end{array}$ & \begin{tabular}{c} 
Oxidative stability \\
\cline { 2 - 4 }$(\mathrm{mg} \mathrm{KOH} / \mathrm{g} \mathrm{DW})$
\end{tabular} & $\begin{array}{c}\text { Peroxide value } \\
(\text { meq/kg DW })\end{array}$ \\
\hline Before air bubble washing & $1.13 \pm 0.01^{1 \mathrm{~d} 2 \mathrm{a})}$ & $2.01 \pm 0.01^{\mathrm{a}}$ \\
\hline $\begin{array}{c}\text { After air } \\
\text { bubble washing }\end{array}$ & 0 & $1.13 \pm 0.01^{\mathrm{a}}$ & $2.01 \pm 0.01^{\mathrm{a}}$ \\
\hline & 1 & $1.13 \pm 0.02^{\mathrm{a}}$ & $2.01 \pm 0.01^{\mathrm{a}}$ \\
Vinegar & 2.5 & $1.15 \pm 0.01^{\mathrm{a}}$ & $2.03 \pm 0.01^{\mathrm{a}}$ \\
& 5 & $1.15 \pm 0.02^{\mathrm{a}}$ & $2.03 \pm 0.02^{\mathrm{a}}$ \\
\hline \multirow{2}{*}{ Salt } & 1 & $1.13 \pm 0.02^{\mathrm{a}}$ & $2.01 \pm 0.01^{\mathrm{a}}$ \\
& 2.5 & $1.13 \pm 0.01^{\mathrm{a}}$ & $2.01 \pm 0.01^{\mathrm{a}}$ \\
& 5 & $1.13 \pm 0.02^{\mathrm{a}}$ & $2.01 \pm 0.01^{\mathrm{a}}$ \\
\hline
\end{tabular}

${ }^{1)}$ All values are mean $\pm \mathrm{SD}(\mathrm{n}=3)$.

${ }^{2}$ Different letters superscript indicate in the same column that means are significantly different $(p<0.05)$ by Duncan's multiple range test.

\section{요 약}

최근 소비와 재배가 증가하고 있는 들깨의 미생물 안전 성을 확보하기 위한 세척기술에 대한 연구가 전무한 실정이 다. 따라서 본 연구는 들깨의 수확 후 관리의 일환으로써 위생적 천연 세척기술을 구축하기 위해 버블세척 시간에 따른 미생물 수를 분석하였고, 천연 세척보조제인 식초와 염수를 이용한 버블세척을 통해 미생물 살균 효과와 산가 및 과산화물가 측정을 통한 산화 안정성에 미치는 영향을 분석하였다. 일반 침지보다 버블세척이 들깨의 미생물 저 감 효과가 우수한 것으로 나타났으며, 버블세척 시간 60 분 이후부터는 유의적으로 미생물 수의 감소가 나타나지 않아 최적 버블세척 시간을 60 분으로 설정하였다. 세척 효율을
증가시키기 위해 천연 세척보조제로 식초와 염을 이용하였 고, $1,2.5,5 \%$ 의 농도로 세척수를 제조하여 들깨의 세척을 실시하였다. 그 결과 세척보조제가 용해된 세척수를 이용 한 경우에도 버블세척이 일반 침지보다 미생물 저감 효과가 우수한 것으로 나타났다. 특히, 들깨의 미생물 세척 효과는 각각 초산 $2.5 \%$ 이상과 염 $2.5 \%$ 이상의 농도로 용해된 세척 수를 이용하여 들깨를 세척하였을 때 보조제 농도 증가에 따른 유의적인 차이가 없는 것으로 나타났다. 또한 초산 $2.5 \%$ 와 염 $2.5 \%$ 로 세척 시 각각 $62.80 \%$ 와 $59.11 \%$ 의 일반세 균 저감률을 나타내어 식초을 이용한 세척이 염수를 이용한 세척보다 미생물 안전성 확립에 더 효과적인 것으로 나타났 다. 천연 세척보조제를 이용한 버블세척이 들깨의 산화 안 정성에 미치는 영향을 알아보기 위해 산가 및 과산화물가를 분석하였고, 그 결과 모든 처리구에서 세척 전 들깨의 산가 및 과산화물가와 차이가 없는 것으로 나타났다. 결과적으 로 천연 세척보조제인 식초와 염수를 이용한 버블세척은 들깨의 품질에 영향을 주지 않으면서 미생물 제어에 효과가 있는 것으로 나타났다. 따라서 천연 세척보조제를 이용한 버블세척은 들깨의 위생적 미생물 안전성을 확보하기 위한 친환경적인 세척 방법으로 적합할 것으로 생각되며, 수확 후 세척 기술이 필요한 재배 농가에서도 유용하게 적용할 수 있을 것으로 생각된다.

\section{감사의 글}

본 논문은 농촌진흥청 연구사업(세부과제번호: PJ012501032018) 의 지원에 의해 이루어진 것임.

\section{References}

1. Ahmed GU (1989) A taxonomic survey of rust fungi of North-Eastern region of India. Indian Phytopathol, 42, 149-150

2. Ahmed GU (1990) Fungal diseases of some medicinal plants from the North-Eastern region of India. Ad Plant Sci, 3, 158-161

3. Chung, IM, Yun SJ, Kim JT, Gwag JG, Sung JD, Suh HS (1995) Test of superoxide dismutase characteristics and antioxidant activity in perilla leaves. Korean J Crop Sci, 40, 504-511

4. Lee JI, Park CB, Son SY (1993) Quality improvement in perilla III. Varietal difference of protein content and amino acid composition in perilla. Korean J Crop Sci, $38,15-22$

5. Ju JI, Choi HG, Kang YS, Seong YG, Lee HB (2012) 
Optimum sowing date for seed production of late-maturing vegetable perilla at green house of middle region. Korean J Crop Sci, 57, 310-315

6. Kim S, Song B, Ju J (2015) Antioxidant activities of Perilla frutescens britton seed extract and its inhibitory effects against major characteristics of cancer cells. J Korean Soc Food Sci Nutr, 44, 208-215

7. Song JH, Park HS (1994) Effect of perilla oil on colon tumor incidence and its relation to eicosanoid levels and fatty acid profiles of tissues in chemical carcinogentreated rats. BMB Rep, 27, 550-557

8. Lee HA, Han JS (2012) Anti-inflammatory effect of Perilla frutescens (L.) Britton var. frutescens extract in LPS-stimulated raw 264.7 macrophages. Prev Nutr Food Sci, 17, 109-115

9. Jang SD, Rho SN (1991) Effect of dietary perilla seed oil on lipid metabolism in rats. Korean J Nutr, 24, 408-419

10. Kim J (2000) Current status in postharvest management with regard to environment protection. Horic Sci Technol, 18, 556-559

11. Yoon BS, Choi SC, Lim SJ, Heo SJ, Choi JK, Kim IJ, Sung J (2016) Chemical properties of cultivating perilla (for seed) soils in Gangwon provine. Paper presented at Annual Meeting of Korean Society of Soil Sciences and Fertilizer, March, Gyeongju, Korea, p 103

12. Lee SA, Youn AR, Kwon KH, Kim BS, Cha HS (2009) Washing effect of micro-bubbles and changes in quality of lettuce (Lactuca sativa L.) during storage. Korean J Food Preserv, 16, 321-326

13. Chung H, Lee J, Lee J (2015) Eco friendly washing, cleaning, remediation by bubble, aeration, ozone and ultrasonic wave. Paper presented at 2015 Korean Geo-Environmental Society Conference ( $15^{\text {th }}$ Anniversary), September 18, Seoul, Korea, p 353-356

14. Kang SW, Lee SM, Chun JY, Choi SG (2014) Microbial reduction of mulberry treated by air bubble washing with co-washing agents. J Agric Life Sci, 48, 329-340

15. Soli KW, Yoshizumi A, Yamakawa M, Mishima T, Honjoh K, Miyamoto T (2011) Application of a combined decontamination method for fresh produce using SAHW, sucrose fatty acid ester and microbubbles. Food Sci Technol, 17, 555-559

16. Park KJ, Lim JH, Kim BK, Kim JC, Jeong JW, Jeong SW (2008) Effect of aqueous chlorine dioxide and citric acid on reduction of Salmonella typhimurium on sprouting radish seeds. Korean J Food Preserv, 15, 754-759

17. Korea Food and Drug Administration (2013) Korea Food Code, Seoul, Korea, p 3-4, 8-11, 18-19, 29-32

18. Solberg M, Buckalew JJ, Chen CM, Schaffner DW, O’Neil K, Mcdowell J, Post LS, Boderck M (1990) Microbiological safety assurance system for foodservice facilities. Food Technol, 44, 68-73

19. Jun SY, Kim TH, Kwon JH, Lee YK (2009) Microbiological evaluation in situ of each process in seed spouting. Korean J Food Preserv, 16, 971-976

20. Oh SY, Choi ST, Kim JG, Lim CI (2005) Removal effects of washing treatments on pesticide residues and microorganisms in leafy vegetables. Korean J Hortic Sci Technol, 23, 250-255

21. Choi JW, Park SY, Yeon JH, Lee MJ, Chung DH, Lee KH, Kim MG, Lee DH, Kim KS, Ha SD (2005) Microbial contamination levels of fresh vegetables distributed in markets. J Food Hyg Saf, 20, 43-47

22. Ziezak D (1986) Antimicrobial agents. Food Technol, 40, 104-109

23. Kim SH, Chung SY (2003) Effect of pre-preparation with vinegar against microorganisms on vegetables in foodservice operations. J Korean Soc Food Sci Nutr, 32, 230-237

24. Kang SW, Lee BH, Heo HJ, Chun JY, Seoung TJ, Choi SG (2011) Effect of air bubble washing with brine on quality characteristics of strawberries during storage. J Agric Life Sci, 45, 81-88

25. Lee KG, Kim SM (2012) Quality changes in low-salted squid Jeot-gal during fermentation and determination of shelf-life. J Korean Soc Food Sci Nurt, 41, 687-694

26. Park SJ, Park KY, Jun HK (2001) Effects of commercial salts on the growth of kimchi-related microorganisms. J Korean Soc Food Sci Nutr, 30, 806-813 